\title{
The Life of a Trailing Spouse
}

\author{
() Vance P. Lemmon \\ The Miami Project to Cure Paralysis, Department of Neurological Surgery and Institute for Data Science and Computing, University of Miami \\ Miller School of Medicine, Miami, Florida 33136
}

In 1981, I published a paper in the first issue of the Journal of Neuroscience with my postdoctoral mentor, Alan Pearlman. It reported a quantitative analysis of the receptive field properties of neurons in reeler mouse visual cortex and the surprising conclusion that although the neuronal somas were strikingly malpositioned, their receptive fields were unchanged. This suggested that in mouse cortex at least, neuronal circuits have very robust systems in place to ensure the proper formation of connections. This had the unintended consequence of transforming me from an electrophysiologist into a cellular and molecular neuroscientist who studied cell adhesion molecules and the molecular mechanisms they use to regulate axon growth. It took me a surprisingly long time to appreciate that your science is driven by the people around you and by the technologies that are locally available. As a professional puzzler, I like all different kinds of puzzles, but the most fun puzzles involve playing with other puzzlers. This is my story of learning how to find like-minded puzzlers to solve riddles about axon growth and regeneration.

In 1978, I was finishing my PhD at Emory and about to become a trailing spouse, headed to Washington University (WashU) to do my postdoc. My wife, Sandy, had taken a leave of absence from her $\mathrm{PhD}$ in WashU's Molecular Biology program when we got married in 1976. I was much closer to finishing at the time, so it seemed the best choice for us. Of course, no one at WashU expected Sandy to come back. They were wrong.

My dissertation project involved retinal degeneration, and I used behavior, electrophysiology, and histology to explore the course of the pathology. When I looked at the neuroscience faculty at WashU, I was amazed at their breadth and depth. Best of all, they had a National Eye Institute (NEI) training grant with postdoc positions. The names of two professors jumped out at me: Nigel Daw and Alan Pearlman. They had been postdocs with David Hubel and Torsten Wiesel and also used behavior,

\footnotetext{
Received Nov. 17, 2020; revised Nov. 22, 2020; accepted Nov. 24, 2020.

Author reflections on developments since the publication of "Does laminar position determine the receptive field properties of cortical neurons? A study of corticotectal cells in area 17 of the normal mouse and the reeler mutant." by Vance Lemmon and Alan L. Pearlman. (1981) J Neurosci 1(1):83-93.

This work was supported by National Eye Institute, National Institute of Neurological Disorders and Stroke, Eunice Kennedy Shriver National Institute of Child Health and Human Development, National Center for Advancing Translational Sciences, National Heart, Lung, and Blood Institute, National Human Genome Research Institute Home, The National Science Foundation, The Department of Defense. The Walter G. Ross Foundation, the Buoniconti Foundation, the March of Dimes, the Craig H. Neilsen Foundation, Ralph Wilson Medical Research Foundation, Paralyzed Veterans of America Grant, Brain Science Institute, RIKEN, The Coulter Foundation, the State of Florida, and the National Society for the Prevention of Blindness over the past 40 years. The author holds Walter G. Ross Distinguished Chair in Developmental Neuroscience.

This article is dedicated to the memory of Mami Yamasaki, a trail blazing pediatric neurosurgeon from Osaka. You can learn about her amazing life at https://www.youtube.com/watch?v=INCiXXtoMV8. It is also dedicated to my wife, Sandra Lemmon. We have been following each other from job to job for over 45 years. Sometimes, it was challenging, but it worked out OK in the end. I also want to thank the members of my lab at various institutions and my many wonderful collaborators. Lastly, I need to apologize to lab members who go unmentioned because of space constraints. It is impossible for me to explain how much fun it has been to work on all these puzzles with them.

The author declares no competing financial interests.

Correspondence should be addressed to Vance Lemmon at vlemmon@miami.edu.

https://doi.org/10.1523/JNEUROSCI.2874-20.2020

Copyright $\odot 2021$ the authors
}

electrophysiology, and histology to study the visual system. They followed the model of their mentors and had a combined lab with shared and separate projects. It seemed like a perfect place to do my postdoc.

I visited to give a talk and learn more about what they were doing. While they were in Boston, Alan became interested in using mouse models to study the visual system and along with his PhD student, Nancy Mangini, was laying the groundwork by studying receptive field properties of neurons in area 17 (V1) of the mouse. Alan wanted to study the connections in the visual system of reeler mice, a mutant discovered at The Jackson Laboratory by Richard Sidman and studied extensively by Verne Caviness. In reeler $(r l / r l)$, the neurons in the cortex are jumbled up because of failures of proper cell migration. It was originally supposed to be part of Nancy's project, but the homozygous reeler mice were very uncooperative and would not survive to adulthood. Nancy had a large breeding colony of heterozygotes, but the homozygous $\mathrm{C} 57 \mathrm{BL} / 6 \mathrm{~J} r l / r l$ rarely survived even as long as a month. About the time I joined the Pearlman group, The Jackson Laboratory offered the $r l / r l$ mice on a new background: C57BL/6J X C3H hybrid mice. The survival problem disappeared. Using methods developed by Nancy, I was able to race through the project in far less time than we had originally imagined.

For me, the coolest part of my studies was a detailed analysis of the receptive field properties of cortico-tectal cells, which I antidromically activated from the superior colliculus. These cells are normally in layer five of the cortex and they have very distinctive properties: omni-directional and high frequency bursts in response to moving targets. The receptive field properties of cortico-tectal neurons in $r \mathrm{l} / \mathrm{rl}$ mice were identical to cortico-tectal cells in normal mice (See Figure 1), although the cell bodies were spread from the bottom to the top of the cortex. Needless to say, we were surprised by this result, but it pointed to the robust ability of axons to find their targets. 
The Chair of Anatomy and Neurobiology at WashU at that time was Max Cowan, an amazing innovator, science politician (President of the Society for Neuroscience and CSO of the HHMI), and editor of the Journal of Comparative Neurology in the 1960s and 1970s (for more about Max, please see Banker, 2018). He became the founding editor of the Journal of Neuroscience and started wandering up and down the halls asking whether anyone had some cool papers that could go into the Society for Neurosciences' new journal. Timing is everything, and Alan and I were lucky to have our paper on reeler visual cortex accepted for the first issue (Lemmon and Pearlman, 1981).

We thought we should confirm our physiological studies by looking at anatomic connections in normal and reeler cortex. Many people at WashU, inspired by Max, helped develop various methods for anterograde and retrograde tracing of axons. The first was an autoradiographic method that used radioactive amino acids injected directly into the brain, an idea from one of Max's PhD students, David Gottlieb. Max's former student, Jennifer LaVail, discovered that horseradish peroxidase (HRP) was retrogradely transported and was a very sensitive reporter. Larry Swanson, one of Max's postdocs, was one of the first to use fluorescent tracers to look at distant neuronal connections. In this environment it was easy to apply these methods to reeler. Working with a new postdoc in the lab, Peter Simmons, we used wheat germ agglutinin-HRP to look at connections between different cortical visual areas. I used an MMS$\mathrm{X}$ minicomputer, originally built for doing $3 \mathrm{D}$ reconstructions of $\mathrm{X}$-ray crystallographic data, to make reconstructions of mouse brains. The visualizations (Figs. 6-8; Simmons et al., 1982) of the paper clearly showed that the patterns of connections between $\mathrm{V} 1, \mathrm{~V} 2$, and V3 were similar in $+/+$ and $r l / r l$ mice See Figure 2. Although I had been using LINC and PDP-8 computers for several years in my electrophysiology experiments, this was the first time I had to undertake a large coding project. Interestingly, most of the code was to prevent operator error during data entry.

Alan and I became fascinated with the cell biology of the migration defect. The Reelin gene was not discovered until 1995 by Tom Curran's lab (D’Arcangelo et al., 1995), but it already seemed like a cell adhesion issue. I was able to attend a NATO conference on Developmental Neuroscience in Erice, Italy, in 1979. It was an amazing course with Victor Hamburger, Nicolle Le Douarin, and many other luminaries. The lecture that was the most interesting to me was by Melitta Schachner on the use of monoclonal antibodies (mABs) to identify different cell types in the brain. I also met one of her postdocs, Carl Lagenaur, at this meeting. It immediately stuck me that mABs could help Alan and me study neuronal migration in reeler brains.

Luckily for me, there was a daring young faculty member at WashU, David Gottlieb. Yes, Max Cowan's former student, who was using mABs to hunt for gradients of cell surface molecules in the chick retina. He had started working on the problem as a postdoc with the Chair of Biochemistry, Luis Glaser. Luis was the Editor-in-Chief of the Journal of Cell Biology at the time, and Sandy had done her first rotation in grad school in his lab. Alan and the professors who ran the NEI training grant let me move to David's lab and join the project. Under David's fabulous mentorship, I learned about the cell biology of cell adhesion and made a number of interesting antibodies, including the first mAB to N-CAM (Lemmon and Gottlieb, 1982), which in the lab we called "superclone." My second paper in the Journal of Neuroscience (Lemmon et al., 1982) was about mABs to the inner retina.

The paper about the superclone $\mathrm{mAB}$ used a novel technique recently developed by Keith Burridge (Burridge, 1978). Laemmli SDS gels had been published in 1970, but Western Blots using electrical transfer was not invented until $\sim 1981$. We were interested in characterizing the antigen recognized by superclone and ran an extract of chick embryo tectum on a gel. We purified some of the $\mathrm{mAB}$, iodinated it with $\mathrm{I}^{125}$ and incubated the gel in the radioactive solution overnight. The gel was washed, dried and exposed to X-ray film. We saw a fuzzy band at the top of the gel at early developmental stages that resolved to three sharp bands at later stages. The reviewers of the paper gave us a hard time about the fuzzy bands, but we made an argument about the role of glycosylation. Although we did not know it at the time, this fuzziness was because of polysialic acid on N-CAM, which is downregulated during development.

In 1981, with my Journal of Neuroscience paper on reeler cortex and $\mathrm{mAB}$ skill set in hand, I got an assistant professorship at the Medical University of South Carolina (MUSC) with Ray and Jenny Lund, two visual system stars. Young faculty and postdocs included Gary Landreth, Steve and Linda McLoon, Gary Blasdel, David Fitzpatrick, and Alan Harvey. I continued to work on the chicken visual system and by using embryonic optic nerve as an immunogen I generated a number of $\mathrm{mABs}$ to axons of retinal ganglion cells. But my tenure at MUSC was short lived because in 1983, Ray and Jenny were recruited to the University of Pittsburgh. I was lucky because they invited me to move with them, but it was annoying to have to reboot my nascent lab after such a short time. A silver lining was that Sandy found a fantastic postdoc at Carnegie Mellon University with Elizabeth Jones, a very famous yeast cell biologist. A second fortuitous thing happened. I convinced Ray that we should hire Carl Lagenaur. Before working with Prof. Schachner, he had earned a $\mathrm{PhD}$ in biochemistry at the University of Washington, and I was sure he would make it possible for us all to make progress much more quickly. 


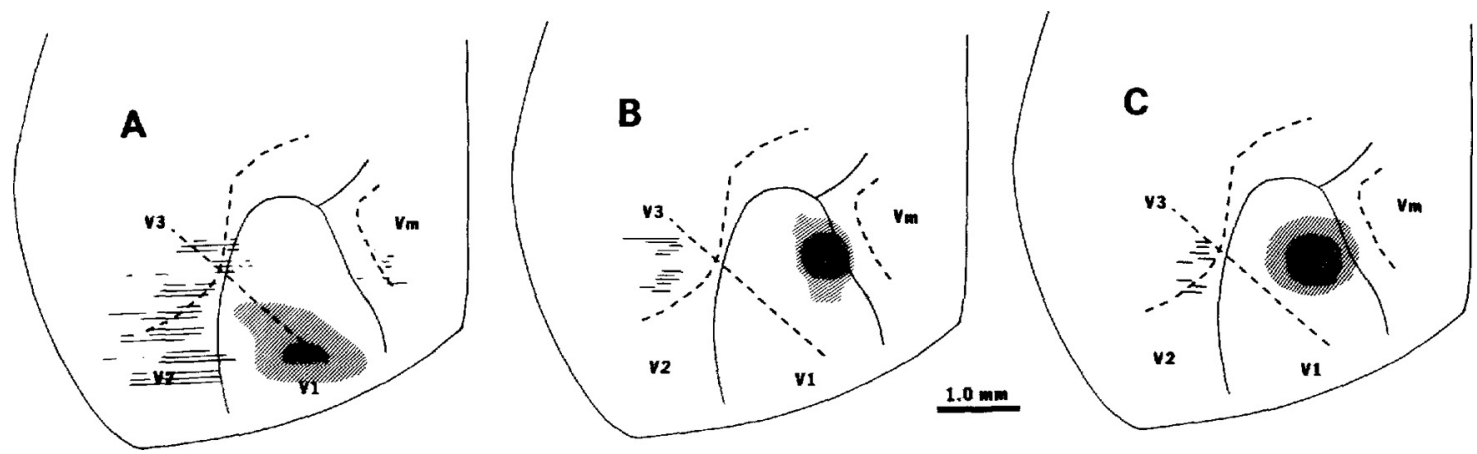

Figure 2. Computer-assisted reconstructions show the pattern of connections between visual areas is similar in normal and reeler mice. Each panel shows the dorsal view of the caudal portion of three brains after injections into area 17 of the visual cortex. All markings represent the projection to the cortical surface of labeling at all cortical depths, excluding the white matter and subcortical sites. Cross hatching indicates the heavily labeled central zone of the injection. Diagonal lines indicate the surrounding zone of peroxidase diffusion. Horizontal lines indicate regions of anterograde and/or retrograde transport. $\boldsymbol{A}$, An injection of unconjugated HRP in a normal mouse. $\boldsymbol{B}$, An injection of HRP-WGA in a normal mouse. $\boldsymbol{C}$, An injection of HRP-WGA in a reeler mouse (Simmons et al., 1982; their Fig. 6).

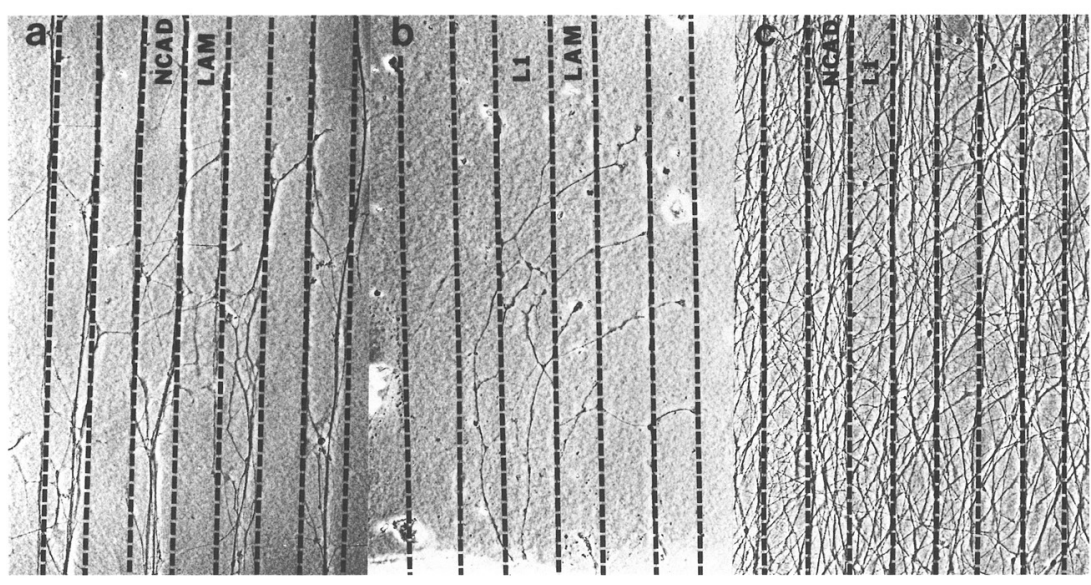

Figure 3. Parallel lane choice experiments testing the importance of adhesion strength for axon guidance. $\boldsymbol{A}$, Neurites crossing alternating lanes of $\mathrm{N}$-cadherin and laminin. $\boldsymbol{B}$, Neurites growing across alternating lanes of $\mathrm{L} 1$ and laminin. $\boldsymbol{C}$, Neurites growing over alternating lanes of N-cadherin and L1 (Lemmon et al., 1992; their Fig. 3).

Carl on various projects. Carl had a great idea of how to spot membrane proteins that he had fractionated on columns onto cell culture plates. We tested the chicken L1-like protein in his assay and found that it was a formidable promoter of axon growth (Lagenaur and Lemmon, 1987). Using clever immunologic tricks, we were able to show that this was because of a homophilic interaction between L1 in the axon and L1 on the plate (Lemmon et al., 1989). Judy also showed that L1 was important in axon growth on Müller glia in the retina, consistent with a heterophilic interaction of $\mathrm{L} 1$ with a receptor on the surface of the glia (Drazba and Lemmon, 1990).

In 1987 Sandy had a paper in Science and an R01 grant, so it was my turn to be a trailing spouse again. It was a bit crazy, as we had two children under 4 , so we had to travel separately. All together, we spent $160 \mathrm{~d}$ traveling for interviews and revisits. In the

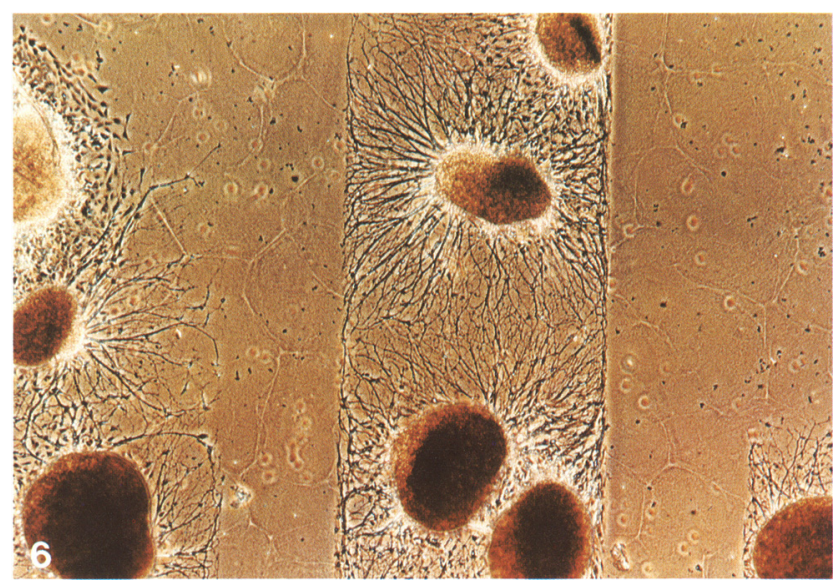

Figure 4. Alternating stripes of N-CAM and N-CAM plus keratin sulfate/CSPGs show a role for these proteoglycans in inhibition during axon guidance. Outgrowth of DRG neurites was inhibited by a mixture of KS/CSPG mixed with polysialylated NCAM (Snow et al., 1990b; their Fig. 6).

I continued working on my mABs to axons and, in 1986, published a paper in Journal of Neuroscience with Steve McLoon on an L1-like molecule in the axons of retinal ganglion cells (Lemmon and McLoon, 1986). I was developing axon outgrowth assays with my student, Judy Drazba, and working with end, we moved to Case Western Reserve University (CWRU) in Cleveland in 1988. Sandy joined the Department of Molecular Biology and Microbiology. I joined a newly formed Center for Neuroscience, headed by Story Landis. Others in the Center at the time were Robert Miller, Jerry Silver, and Richard Zigmond. Shortly thereafter, my friend from MUSC, Gary Landreth, an expert on neural growth factor signaling, and Karl Herrup, an expert on cerebellar development and cell linage, moved to CWRU as well. Urs Rutishauser, one of the discoverers of N-CAM in Gerald Edelman's group, was also there, and his lab was next to mine. Then Lynn Landmesser joined us. It was a small group, but it had stunning firepower in developmental neuroscience.

By 1988, Judy's experiments and studies by Kevin Tomaselli and John Bixby in Lou Reichardt's lab at University of California, San Francisco had convinced me that axonal CAMs were doing things that were no longer explained by Malcom Steinberg's differential adhesion hypothesis (Steinberg, 1962). They had to be acting as signaling molecules. I gave a lecture about this in a course I was teaching with Urs and he got quite excited. We worked with Gary Landreth and did some experiments showing that pharmacological alteration of phosphorylation blocked the ability of anti-CAM Fabs to cause defasciculation. 
This was published in Proceedings of the National Academy of Sciences of the United States of America (Cervello et al., 1991) .

At CWRU, I had great students and a series of Japanese postdocs who took things to a new level. With Sue BurdenGulley, I published two papers in Journal of Neuroscience (Lemmon et al., 1992; Burden-Gulley et al., 1995) The most important one showed that strength of adhesion was not as important in the choices that growth cones make as it had been cracked up to be (Lemmon et al., 1992). Part of this project involved making lanes of alternating CAMs to see which CAMs the axons preferred to grow on. I, of course, predicted they would prefer L1 over laminin or N-cadherin. I was wrong. Axons would happily wander from one to the next (See Figure 3).

I heard a seminar by one of Jerry Silver's students about chondroitin sulfate proteoglycans (CSPGs) in the glial roof plate of the spinal cord, which they thought might be an inhibitory barrier for axon growth (Snow et al., 1990a). I proposed to Jerry that we test CSPGs in our alternating lane assay. His student Diane Snow did the experiments in my lab and, sure enough, CSPGs were very inhibitory (See Figure 4). The 1990 paper with Diane and Jerry has the most citations of any of my papers (Snow et al., 1990b). This was before the demonstration that collapsin/semaphorin $3 \mathrm{~A}$ and ephrins had major roles in axon guidance, so we did not at the time appreciate how important inhibitory signals are as a general principle for axon guidance in the developing brain.

About the time I moved to CWRU, it was clear that we would have to take the leap into molecular biology if we wanted to make progress on the mechanism of action of L1. I had been reluctant, because I thought our lab would be crushed by the Edelman lab and the Schachner lab. The Schachner lab published the mouse L1 cDNA sequence in 1988 (Moos et al., 1988). Working with Lulu Hlavin, a neurosurgery resident doing research in my lab, we used hints from the mouse sequence to clone the human L1 cDNA (Hlavin and Lemmon, 1991). As soon as the paper was published, I got faxes from human geneticists in the United Kingdom and Belgium asking for the cDNA. We sent them plasmids, and in short order, both labs demonstrated that mutations in the $L 1$ gene caused a horrible birth defect called X-linked hydrocephalus (Rosenthal et al., 1992; Van Camp et al., 1993). Mami Yamasaki, a pediatric neurosurgeon from Osaka National Hospital, joined my lab in 1996 to work on X-linked hydrocephalus. Using hints from the genotype/phenotype correlations in humans, we proposed a number of ideas about the roles of different parts of the L1 protein (Yamasaki et al., 1997; Kamiguchi et al., 1998a). Dr. Yamasaki subsequently became the first woman chair of a neurosurgery department in Japan. Working with
Kyoko Itoh, Shinji Fushiki, Yoshimasa Kamei, Suni Lee, and Yukiko Nakamura, we made various knock-outs and knock-ins in mice to test these ideas (Itoh et al., 2004, 2005; Nakamura et al., 2010). There were a number of unexpected observations, including that removal of the sixth Ig domain, resulting in a loss of L1-L1 homophilic binding, did not produce the axon guidance defects of the corticospinal tract observed in the $L 1$ knock-out, implying some heterophilic receptor was involved with L1 in mediating the decussation of the axons at the pyramids (for the likely explanation, see Bechara et al., 2008). Another was that if the ankyrin binding site was removed in the L1 cytoplasmic domain, brain development appeared fairly normal and L1 expression was fine during development. But in the adult, L1 disappeared and the mice had motor defects in a rotarod test. I am very proud of my Japanese colleagues. They are all successful faculty members. Kyoko is one of only two female chairs of neuropathology 

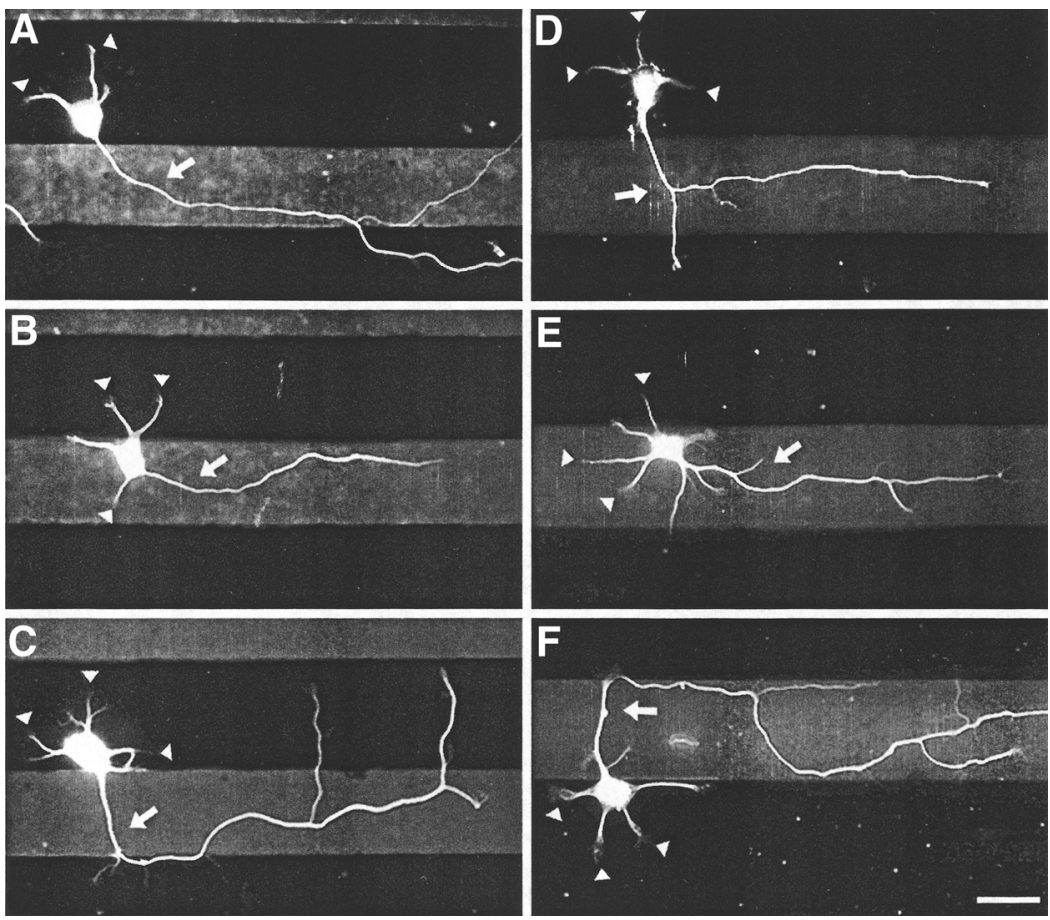

Figure 6. When hippocampal neurons are grown on striped substrates, axons form predominantly on one substrate Neurons were cultured on substrates patterned with alternating stripes of polylysine and laminin $(\boldsymbol{A}-\boldsymbol{C})$ or polylysine and $\operatorname{NgCAM}(\boldsymbol{D}-\boldsymbol{F})$. When neurons were examined after $24 \mathrm{~h}$ in culture, minor process growth cones (arrowheads) were positioned on both substrates, but axons (arrows) almost always formed on laminin or $\mathrm{NgCAM}$. Neurons were immunolabeled for tubulin, and the patterns were revealed by immunostaining for either laminin or $\mathrm{NgCAM}$ so that polylysine appears dark and L laminin $\mathrm{N}$ or $\mathrm{NgCAM}$ appears light. Fluorescent images of neurons and stripes were superimposed. Scale bar: $25 \mathrm{~mm}$ (Esch et al., 2000; their Fig. 1).
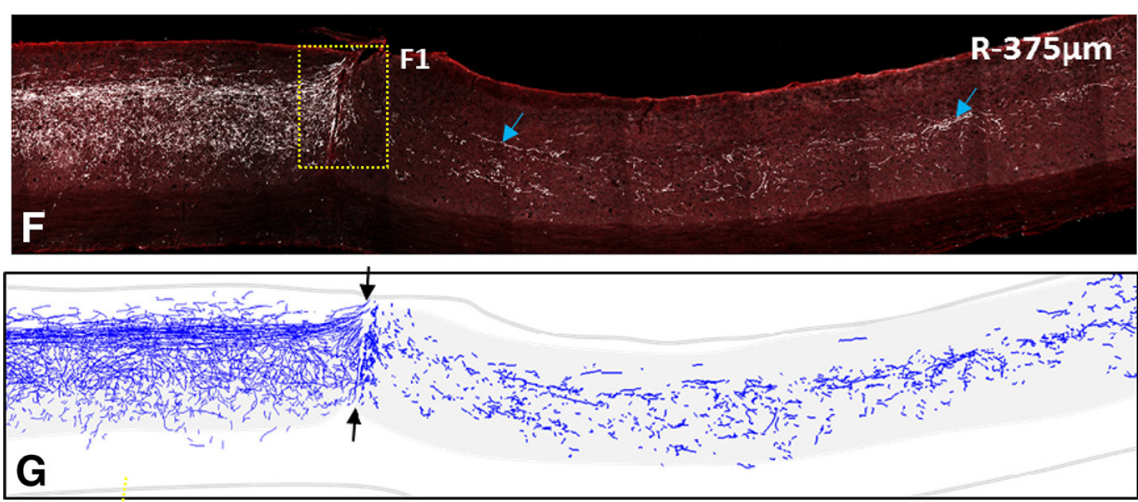

Figure 7. The kinase inhibitor PF-4708671 promoted robust axonal regeneration of the corticospinal tract through and beyond the dorsal hemisection of the spinal cord. $\boldsymbol{F}$, A parasagittal section of the spinal cord, from an animal that received $10 \mathrm{~mm}$ PF-4708671 shows corticospinal tract axonal regeneration across and beyond the lesion gap. The regenerated axons elongated within the distal spinal gray matter for considerable distances (blue arrows). $\mathbf{G}$, Neurolucida reconstruction of the single section from $\boldsymbol{F}$ shows the lesion gap far beyond the main dorsal corticospinal tract (between two arrows). Varicosities of regenerated corticospinal tract axons extended within the distal spinal gray matter for considerable distances (from Al-Ali et al., 2017; their Fig. 9F,G).

departments in Japan and Kamei is Chair of ObGyn at Saitama Medical University.

Hiroyuki Kamiguchi (currently the Acting Director of RIKEN Center for Brain Science) was a powerhouse in my lab at CWRU (1996-98). He noticed that the L1 cytoplasmic domain had a potential tyrosine-based sorting sequence that could, in theory, bind the AP-2 clathrin adaptor. He came up with the astute idea that L1-dependent growth cone migration could be regulated by localized recycling of $\mathrm{L} 1$. This led to three papers and one cover (See Figure 5) in J Neurosci (Kamiguchi and Lemmon, 1998, 2000; Kamiguchi et al., 1998b) and papers in Journal of Biological Chemistry and Journal of Cell Biology (Schaefer et al., 1999, 2002; Itoh et al., 2004). Eric Wong, Andy Schaefer, and Ling Cheng identified several L1 cytoplasmic domain binding proteins that regulate interactions with the cytoskeleton and modulate signaling pathways (Wong et al., 1996a,b; Schaefer et al., 1999, 2002; Cheng and Lemmon, 2004; Cheng et al., 2005a,b).

Gary Banker, another student of Max Cowan, had been studying how hippocampal neurons became polarized for many years. He proposed that it was a stochastic process, where one of the neurites became longer than the others by some random process and was designated to become the axon, in a "winner take all interaction," while other neurites became dendrites (Mandell and Banker, 1995). The famous Dotti, Sullivan, and Banker J Neurosci paper on the establishment of polarity of hippocampal neurons used a poly-L-lysine substrate for the experiments (Dotti et al., 1988). From my CAM-centric view of the world, I thought maybe L1 could stimulate axon polarization if presented in some pattern to Gary's neurons. I was half right. Gary's student, Teresa Esch, tested the ability of both laminin and L1 to stimulate axon growth using alternating lanes of polylysine. The axons would almost always form on the laminin or L1. But something really interesting happened with alternating lanes of laminin and L1. The axons would form on the substrate adjacent to the location where the soma attached. If the neuron landed on L1, an axon would form when a neurite touched a laminin lane and vice versa. One explanation is that that when a neurite encounters a favorable substrate, the resulting acceleration in neurite extension generates a signal that turns that process into an axon. This result was published in Journal of Neuroscience in 1999 (See Figure 6), (Esch et al., 1999).

In 2003, I moved to The Miami Project to Cure Paralysis at the University of Miami. Serendipitously, John Bixby was a professor at the University of Miami (UM) and directed the Neuroscience Program. Besides chairing the search committee that recruited me, he had done two things to make the job really attractive. First, he persuaded UM to target an endowed chair in Developmental Neuroscience for this position, and second, he and a psychology professor named Phil McCabe had successfully competed for $\$ 1.7$ million in neuroscience funding from the Provost's Office, which made my startup package possible. Thinking back on my productive time with Alan and Nigel, I suggested to John (a former competitor in the CAM field) that 
we merge our labs, an idea that has since become the LemBix lab. He thought it was an intriguing (i.e., crazy) idea, especially since we had never collaborated on anything. I convinced him that since it was an open lab plan research building, if it did not work out, we would be OK. It was not like we were getting married.

The support I obtained from my boss, Dalton Dietrich, and the Provost (Luis Glaser; yes, that Luis Glaser from WashU) allowed John and me to make a big leap to a new research area (regeneration after injury) and start applying two high throughput methods to studies of axon regeneration. The first was high content analysis (HCA). This approach uses an automated microscope designed to image cells in multi-well dishes combined with automated image analysis to measure many aspects of cell morphology along with the locations of various cellular components. In our case, we measured the lengths of neurites, along with their numbers and branchiness. We acquired a lot of images. In fact, we made life difficult for the UM IT department, and they complained that we required more data storage space than any other lab at UM. Eventually, the people studying ocean and atmospheric science and the geneticists overtook us.

We also started using various high-throughput methods to study the transcriptomics of neurons that were either capable or incapable of axon regeneration. This led to experiments using microarrays and RNA-seq to identify transcription factors and microRNAs that could regulate axon growth. Two $\mathrm{PhD}$ students with engineering backgrounds, Robin Smith and Willie Buchser, really got us going with the electroporation, automation and data analysis tools needed to perform HCA experiments on primary neurons (Buchser et al., 2004, 2006; Lemmon et al., 2011) and to analyze the consequent flood of sequencing data (Smith et al., 2008). Their work established kinases and transcription factors as major targets for regeneration that we still work on (Blackmore et al., 2010; Buchser et al., 2010, 2012; Smith et al., 2011).

A postdoc who joined our group, Murray Blackmore, wanted to use clues from changes in gene expression during development to flag genes for HCA testing. We launched a collaboration with Jeff Goldberg, a young faculty member in the ophthalmology department, and his student, Darcie Moore. In short order Murray and Darcie identified the KLF family of transcription factors as important regulators of the intrinsic ability of axons to regenerate in the adult, leading to two high impact publications (Moore et al., 2009; Blackmore et al., 2012).

It was pretty clear that the LemBix lab needed to change the way we viewed and managed our data. We had moved from studying things a few at a time to the velocity, variety, veracity, and volume problems of big data. One person we started talking to was Stephan Schürer, a cheminformaticist who had recently come to UM from Scripps Florida High Throughput Screening Center. Another was Mitsu Ogihara, a UM computer scientist. This had the unintended consequence of Stephan and I working together on a project to develop an ontology to describe bioassays in PubChem, a large repository for screens conducted at NIH supported screening centers (Schürer et al., 2011; Visser et al., 2011; Vempati et al., 2012; Abeyruwan et al., 2014). This, in turn, inspired John Bixby and me to create an ontology and minimal information standard for the spinal cord injury (SCI) domain in collaboration with three experts on semantics: Ubbo Visser from UM, and Alison Callahan and Nigam Shah from Stanford (Callahan et al., 2016, 2017; Fouad et al., 2020). We are still working on this issue with colleagues in the SCI community.
We have also continued to work on transcription factors and epigenetic control of regeneration with a remarkable group of postdocs and $\mathrm{PhD}$ students who are equally at home at the bench and running scripts on high performance computing clusters. One student in particular, Matt Danzi, has been the vector for a collaboration with Simone di Giovanni's lab that has led to a series of papers in high impact journals (Hervera et al., 2018, 2019; Hutson et al., 2019; Palmisano et al., 2019). Besides Ubbo, Stephan Wuchty and Zheng Wang in the UM Computer Science Department have been instrumental in our progress (Palmisano et al., 2019; Devkota et al., 2020). My participation in their NSF training grant has provided great undergrads to help us to tackle challenging problems with artificial intelligence.

In 2010, Hassan Al-Ali joined our team. He is a biochemist and computational scientist with expertise in kinases. He was interested in learning about drug discovery. We screened a large number of kinase inhibitors and with some guidance from Mitsu, we developed a machine learning method to identify kinases, such as S6K (Al-Ali et al., 2015b; Al-Ali et al., 2017) that should be inhibited to promote axon growth (See Figure 7), along with those that should not be inhibited. Using this approach, we have identified a kinase inhibitor with excellent polypharmacology that promotes robust axon regeneration in different mouse models of SCI (Al-Ali et al., 2015a). We hope it will someday lead to an effective therapy for SCI.

John and I have now screened over 440 million compounds, cDNAs, miRNAs, and siRNAs on primary neurons. That is a record that is unlikely to be broken in the near future. We have published 55 papers together so far, including two Science papers, one Proceedings of the National Academy of Sciences of the United States of America paper, one Nature Neuroscience, and three papers in J Neurosci. John now admits my "crazy idea" was, after all, not so bad. Sandy is a Professor of Molecular and Cellular Pharmacology and longtime Director of the University of Miami MD/PhD program. She too admits her latest turn at being the trailing spouse worked out just fine.

As a student and postdoc, I was taught how to design, perform, and interpret experiments. I naively thought those were the core skills I needed to be a successful scientist. I learned a lot from some mistakes I made in building my team as an assistant professor. I also noticed the amount of time more senior scientists devoted to "politics." It began to dawn on me that my job as a PI was more about building an effective team and finding other groups that were synergistic with ours so we could tackle difficult problems. I am sure that my decision in the early 1990s to be much more proactive about networking has helped our team to be as successful as it has been. Certainly, it has made it a lot more fun.

\section{The Authors, Four Decades On}

Alan Pearlman is Professor Emeritus of Cell Biology and Neurology at Washington University School of Medicine. He was a physician scientist and continued to work on reeler and the cell biology of neuronal migration, teach in neurology and neuroscience courses, and see patients in Neurology at WashU for another 20 years. After he retired, he moved to New Mexico, where he volunteers in two Family Practice clinics that serve uninsured and underinsured patients, assisting residents and providers with their neurologic patients, and pursues his lifelong interest in photography.

Vance Lemmon holds the Walter G. Ross Distinguished Chair in Developmental Neuroscience and is a Professor of 
Neurologic Surgery in The Miami Project to Cure Paralysis. He is also the Program Director in Computational Biology in the Institute for Data Science and Computing at the University of Miami. You can read the latest news about projects in his merged lab with John Bixby at https://www.lembixlab.net/. In their spare time, Sandy and Vance enjoy riding their bikes in interesting places around the world.

\section{References}

Abeyruwan S, Vempati UD, Küçük-McGinty H, Visser U, Koleti A, Mir A, Sakurai K, Chung C, Bittker JA, Clemons PA, Brudz S, Siripala A, Morales AJ, Romacker M, Twomey D, Bureeva S, Lemmon V, Schürer SC (2014) Evolving BioAssay ontology (BAO): modularization, integration and applications. J Biomed Sem 5:S5.

Al-Ali H, Lee DH, Danzi MC, Nassif H, Gautam P, Wennerberg K, Zuercher B, Drewry DH, Lee JK, Lemmon VP, Bixby JL (2015) Rational polypharmacology: systematically identifying and engaging multiple drug targets to promote axon growth. ACS Chem Biol 10:1939-1951.

Al-Ali H, Ding Y, Slepak T, Wu W, Sun Y, Martinez Y, Xu XM, Lemmon VP, Bixby JL (2017) The mTOR substrate S6 kinase 1 (S6K1) is a negative regulator of axon regeneration and a potential drug target for central nervous system injury. J Neurosci 37:7079-7095.

Banker G (2018) The development of neuronal polarity: a retrospective view. J Neurosci 38:1867-1873.

Bechara A, Nawabi H, Moret F, Yaron A, Weaver E, Bozon M, Abouzid K, Guan JL, Tessier-Lavigne M, Lemmon V, Castellani V (2008) FAKMAPK-dependent adhesion disassembly downstream of L1 contributes to semaphorin3A-induced collapse. EMBO J 27:1549-1562.

Blackmore MG, Moore DL, Smith RP, Goldberg JL, Bixby L, Lemmon VP (2010) High content screening of cortical neurons identifies novel regulators of axon growth. Mol Cell Neurosci 44:43-54.

Blackmore MG, Wang Z, Lerch JK, Motti D, Zhang YP, Shields CB, Lee JK, Goldberg JL, Lemmon VP, Bixby JL (2012) Kruppel-like Factor 7 engineered for transcriptional activation promotes axon regeneration in the adult corticospinal tract. Proc Natl Acad Sci USA 109:7517-7522.

Buchser W, Collins M, Garyantes T, Guha R, Haney S, Lemmon V, Li Z, Trask OJ (2004) Assay development guidelines for image-based high content screening, high content analysis and high content imaging. In: Assay guidance manual (Sittampalam GS, Coussens NP, Nelson H, Arkin M, Auld D, Austin C, Bejcek B, Glicksman M, Inglese J, Iversen PW, Li Z. McGee J, McManus O, Minor L, Napper A, Peltier JM, Riss T, Trask OJ $\mathrm{Jr}$, Weidner J, eds). Bethesda: National Institutes of Health.

Buchser WJ, Pardinas JR, Shi Y, Bixby JL, Lemmon VP (2006) 96-well electroporation method for transfection of mammalian central neurons. Biotechniques 41:619-624.

Buchser WJ, Slepak TI, Gutierrez-Arenas O, Bixby JL, Lemmon VP (2010) Kinase/phosphatase overexpression reveals pathways regulating hippocampal neuron morphology. Mol Syst Biol 6:391.

Buchser WJ, Smith RP, Pardinas JR, Haddox CL, Hutson T, Moon L, Hoffman SR, Bixby JL, Lemmon VP (2012) Peripheral nervous system genes expressed in central neurons induce growth on inhibitory substrates. PLoS One 7:e38101.

Burden-Gulley SM, Payne HR, Lemmon V (1995) Growth cones are actively influenced by substrate-bound adhesion molecules. J Neurosci 15:43704381.

Burridge K (1978) Direct identification of specific glycoproteins and antigens in sodium dodecyl sulfate gels. Methods Enzymol 50:54-64.

Callahan A, Abeyruwan SW, Al-Ali H, Sakurai K, Ferguson AR, Popovich PG, Shah NH, Visser U, Bixby JL, Lemmon VP (2016) RegenBase: a knowledge base of spinal cord injury biology for translational research. Database 2016:baw040.

Callahan A, Anderson KD, Beattie MS, Bixby JL, Ferguson AR, Fouad K, Jakeman LB, Nielson JL, Popovich PG, Schwab JM, Lemmon VP, FAIR Share Workshop Participants (2017) Developing a data sharing community for spinal cord injury research. Exp Neurol 295:135-143.

Cervello M, Lemmon V, Landreth G, Rutishauser U (1991) Phosphorylationdependent regulation of axon fasciculation. Proc Natl Acad Sci USA 88:10548-10552.

Cheng L, Lemmon V (2004) Pathological missense mutations of neural cell adhesion molecule L1 affect neurite outgrowth and branching on an L1 substrate. Mol Cell Neurosci 27:522-530.
Cheng L, Lemmon S, Lemmon V (2005a) RanBPM is an L1-interacting protein that regulates L1-mediated mitogen-activated protein kinase activation. J Neurochem 94:1102-1110.

Cheng L, Itoh K, Lemmon V (2005b) L1-mediated branching is regulated by two ezrin-radixin-moesin (ERM)-binding sites, the RSLE region and a novel juxtamembrane ERM-binding region. J Neurosci 25:395-403.

D’Arcangelo GG, Miao G, Chen SC, Soares HD, Morgan JI, Curran T (1995) A protein related to extracellular matrix proteins deleted in the mouse mutant reeler. Nature 374:719-723.

Devkota P, Danzi MC, Lemmon VP, Bixby JL, Wuchty S (2020) Computational identification of kinases that control axon growth in mouse. SLAS Discov 25:792-800.

Dotti CG, Sullivan CA, Banker GA (1988) The establishment of polarity by hippocampal neurons in culture. J Neurosci 8:1454-1468.

Drazba J, Lemmon V (1990) The role of cell adhesion molecules in neurite outgrowth on Muller cells. Dev Biol 138:82-93.

Esch T, Lemmon V, Banker G (1999) Local presentation of substrate molecules directs axon specification by cultured hippocampal neurons. J Neurosci 19:6417-6426.

Esch T, Lemmon V, Banker G (2000) Differential effects of NgCAM and Ncadherin on the development of axons and dendrites by cultured hippocampal neurons. J Neurocytol 29:215-223.

Fouad K, Bixby JL, Callahan A, Grethe JS, Jakeman LB, Lemmon VP, Magnuson DSK, Martone ME, Nielson JL, Schwab JM, Taylor-Burds C, Tetzlaff W, Torres-Espin A, Ferguson AR, Alam S, Bacon M, Bambrick L, Basso M, Beattie M, Bresnahan J, et al. (2020) Participants F-SAW FAIR SCI ahead: the evolution of the open data commons for pre-clinical spinal cord injury research. J Neurotrauma 37:831-838.

Hervera A, De Virgiliis F, Palmisano I, Zhou L, Tantardini E, Kong G, Hutson T, Danzi MC, Perry RB, Santos CXC, Kapustin AN, Fleck RA, Del Río JA, Carroll T, Lemmon V, Bixby JL, Shah AM, Fainzilber M, Di Giovanni S (2018) Reactive oxygen species regulate axonal regeneration through the release of exosomal NADPH oxidase 2 complexes into injured axons. Nat Cell Biol 20:307-319.

Hervera A, Zhou L, Palmisano I, McLachlan E, Kong G, Hutson TH, Danzi MC, Lemmon VP, Bixby JL, Matamoros-Angles A, Forsberg K, De Virgiliis F, Matheos DP, Kwapis J, Wood MA, Puttagunta R, Del Río JA, Di Giovanni S (2019) PP4-dependent HDAC3 dephosphorylation discriminates between axonal regeneration and regenerative failure. EMBO J 38:e101032.

Hlavin ML, Lemmon V (1991) Molecular structure and functional testing of human L1CAM: an interspecies comparison. Genomics 11:416-423.

Hutson TH, Kathe C, Palmisano I, Bartholdi K, Hervera A, De Virgiliis F, McLachlan E, Zhou L, Kong G, Barraud Q, Danzi MC, MedranoFernandez A, Lopez-Atalaya JP, Boutillier AL, Sinha SH, Singh AK, Chaturbedy P, Moon LDF, Kundu TK, Bixby JL, et al. (2019) Cbp-dependent histone acetylation mediates axon regeneration induced by environmental enrichment in rodent spinal cord injury models. Sci Transl Med 11:eaaw2064.

Itoh K, Cheng L, Kamei Y, Fushiki S, Kamiguchi H, Gutwein P, Stoeck A, Arnold B, Altevogt P, Lemmon V (2004) Brain development in mice lacking L1-L1 homophilic adhesion. J Cell Biol 165:145-154.

Itoh K, Fushiki S, Kamiguchi H, Arnold B, Altevogt P, Lemmon V (2005) Disrupted Schwann cell-axon interactions in peripheral nerves of mice with altered L1-integrin interactions. Mol Cell Neurosci 30:131-136.

Kamiguchi H, Lemmon V (1998) A neuronal form of the cell adhesion molecule L1 contains a tyrosine-based signal required for sorting to the axonal growth cone. J Neurosci 18:3749-3756.

Kamiguchi H, Lemmon V (2000) Recycling of the cell adhesion molecule L1 in axonal growth cones. J Neurosci 20:3676-3686.

Kamiguchi H, Hlavin ML, Yamasaki M, Lemmon V (1998a) Adhesion molecules and inherited diseases of the human nervous system. Annu Rev Neurosci 21:97-125.

Kamiguchi H, Long KE, Pendergast M, Schaefer AW, Rapoport I, Kirchhausen T, Lemmon V (1998b) The neural cell adhesion molecule L1 interacts with the AP-2 adaptor and is endocytosed via the clathrinmediated pathway. J Neurosci 18:5311-5321.

Lagenaur C, Lemmon V (1987) An L1-like molecule, the 8D9 antigen, is a potent substrate for neurite extension. Proc Natl Acad Sci USA 84:77537757. 
Lemmon V, Pearlman AL (1981) Does laminar position determine the receptive field properties of cortical neurons? A study of corticotectal cells in area 17 of the normal mouse and the reeler mutant. J Neurosci 1:83-93.

Lemmon V, Gottlieb DI (1982) Monoclonal antibodies selective for the inner portion of the chick retina. J Neurosci 2:531-535.

Lemmon V, McLoon SC (1986) The appearance of an L1-like molecule in the chick primary visual pathway. J Neurosci 6:2987-2994.

Lemmon V, Staros EB, Perry HE, Gottlieb DI (1982) A monoclonal antibody which binds to the surface of chick brain cells and myotubes: cell selectivity and properties of the antigen. Brain Res 255:349-360.

Lemmon V, Farr KL, Lagenaur C (1989) L1-mediated axon outgrowth occurs via a homophilic binding mechanism. Neuron 2:1597-1603.

Lemmon V, Burden SM, Payne HR, Elmslie GJ, Hlavin ML (1992) Neurite growth on different substrates: permissive versus instructive influences and the role of adhesive strength. J Neurosci 12:818-826.

Lemmon VP, Jia Y, Shi Y, Holbrook SD, Bixby JL, Buchser W (2011) Challenges in small screening laboratories: implementing an on-demand laboratory information management system. CCHTS 14:742-748.

Mandell JW, Banker GA (1995) The microtubule cytoskeleton and the development of neuronal polarity. Neurobiol Aging 16:229-237; discussion 238.

Moore DL, Blackmore MG, Hu Y, Kaestner KH, Bixby JL, Lemmon VP, Goldberg JL (2009) KLF family members regulate intrinsic axon regeneration ability. Science 326:298-301.

Moos M, Tacke R, Scherer H, Teplow D, Früh K, Schachner M (1988) Neural adhesion molecule L1 as a member of the immunoglobulin superfamily with binding domains similar to fibronectin. Nature 334:701-703.

Nakamura Y, Lee S, Haddox CL, Weaver EJ, Lemmon VP (2010) Role of the cytoplasmic domain of the L1 cell adhesion molecule in brain development. J Comp Neurol 518:1113-1132.

Palmisano I, Danzi MC, Hutson TH, Zhou L, McLachlan E, Serger E, Shkura K, Srivastava PK, Hervera A, Neill NO, Liu T, Dhrif H, Wang Z, Kubat M, Wuchty S, Merkenschlager M, Levi L, Elliott E, Bixby JL, Lemmon VP, et al. (2019) Epigenomic signatures underpin the axonal regenerative ability of dorsal root ganglia sensory neurons. Nat Neurosci 22:19131924.

Rosenthal A, Jouet M, Kenwrick S (1992) Aberrant splicing of neural cell adhesion molecule L1 mRNA in a family with X-linked hydrocephalus. Nat Genet 2:107-112.

Schaefer AW, Kamiguchi H, Wong EV, Beach CM, Landreth G, Lemmon V (1999) Activation of the MAPK signal cascade by the neural cell adhesion molecule L1 requires L1 internalization. J Biol Chem 274:37965-37973.

Schaefer AW, Kamei Y, Kamiguchi H, Wong EV, Rapoport I, Kirchhausen T, Beach CM, Landreth G, Lemmon SK, Lemmon V (2002) L1 endocytosis is controlled by a phosphorylation-dephosphorylation cycle stimulated by outside-in signaling by L1. J Cell Biol 157:1223-1232.

Schürer SC, Vempati U, Smith R, Southern M, Lemmon V (2011) BioAssay ontology annotations facilitate cross-analysis of diverse high-throughput screening data sets. J Biomol Screen 16:415-426.

Simmons PA, Lemmon V, Pearlman AL (1982) Afferent and efferent connections of the striate and extrastriate visual cortex of the normal and reeler mouse. J Comp Neurol 211:295-308.

Smith RP, Buchser WJ, Lemmon MB, Pardinas JR, Bixby JL, Lemmon VP (2008) EST Express: PHP/MySQL based automated annotation of ESTs from expression libraries. BMC Bioinformatics 9:186

Smith RP, Lerch-Haner JK, Pardinas JR, Buchser WJ, Bixby JL, Lemmon VP (2011) Transcriptional profiling of intrinsic PNS factors in the postnatal mouse. Mol Cell Neurosci 46:32-44.

Snow DM, Steindler DA, Silver J (1990a) Molecular and cellular characterization of the glial roof plate of the spinal cord and optic tectum: a possible role for a proteoglycan in the development of an axon barrier. Dev Biol 138:359-376.

Snow DM, Lemmon V, Carrino DA, Caplan AI, Silver J (1990b) Sulfated proteoglycans in astroglial barriers inhibit neurite outgrowth in vitro. Exp Neurol 109:111-130.

Steinberg MS (1962) On the mechanism of tissue reconstruction by dissociated cells. I. Population kinetics, differential adhesiveness. and the absence of directed migration. Proc Natl Acad Sci USA 48:1577-1582.

Van Camp G, Vits L, Coucke P, Lyonnet S, Schrander-Stumpel C, Darby J, Holden J, Munnich A, Willems PJ (1993) A duplication in the L1CAM gene associated with X-linked hydrocephalus. Nat Genet 4:421-425.

Vempati UD, Przydzial MJ, Chung C, Abeyruwan S, Mir A, Sakurai K, Visser U, Lemmon VP, Schürer SC (2012) Formalization, annotation and analysis of diverse drug and probe screening assay datasets using the BioAssay ontology (BAO). PLoS One 7:e49198.

Visser U, Abeyruwan S, Vempati U, Smith RP, Lemmon V, Schürer SC (2011) BioAssay Ontology (BAO): a semantic description of bioassays and high-throughput screening results. BMC Bioinformatics 12:257.

Wong EV, Schaefer AW, Landreth G, Lemmon V (1996a) Involvement of p90rsk in neurite outgrowth mediated by the cell adhesion molecule L1. J Biol Chem 271:18217-18223.

Wong EV, Schaefer AW, Landreth G, Lemmon V (1996b) Casein kinase II phosphorylates the neural cell adhesion molecule L1. J Neurochem 66:779-786.

Yamasaki M, Thompson P, Lemmon V (1997) CRASH syndrome: mutations in L1CAM correlate with severity of the disease. Neuropediatrics 28:175178. 